\title{
Pengelolaan Tanah dalam Pengetahuan Lokal dan Praktik Pertanian Berkelanjutan pada Masyarakat Arfak, Papua Barat
}

\section{(Indigenous Knowledge Land Management and Agriculture Sustainable Practices Among Arfak People in Papua Barat)}

\author{
Merry Toansiba, Els Tieneke Rieke Katmo*, Krisnawati, Yustina Linda Dina Wambrauw
}

(Diterima Maret 2020/Disetujui Mei 2021)

\begin{abstract}
ABSTRAK
Lahan sebagai salah satu faktor produksi membutuhkan pengelolaan yang baik terutama di daerah Pegunungan Arfak yang bertopografi ekstrem. Keanekaragaman hayati yang tinggi di sini menjadikan wilayah ini sebagai daerah konservasi dan iklimnya membuat Pegunungan Arfak menjadi sentra produksi sayuran dataran tinggi di Provinsi Papua Barat. Penelitian di kampung Indud, Ubesia dan Taigei, ini bertujuan mendeskripsikan bagaimana petani Arfak menerapkan pengetahuan lokal mereka, yakni konsep igya ser hanjob dalam mengelola tanah guna mendukung usaha tani sayuran dataran tinggi yang berkelanjutan. Penelitian ini menggunakan pendekatan kualitatif dengan metode induktif dan teknik studi kasus untuk mendokumentasikan pengetahuan dan pengalaman $\mathbf{3 0}$ orang petani Arfak dalam sistem usahatani sayuran dataran tinggi yang dipilih dengan teknik snowball. Data dikumpulkan melalui wawancara (individu dan kelompok) dan pengamatan. Penelitian ini menemukan bahwa pengelolaan tanah berkelanjutan dalam kegiatan usaha tani sayuran dataran tinggi berbasis pada konsep ekologi masyarakat Arfak, yakni igya ser hanjob. Konsep ini mengatur wilayah kelola yang tepat untuk keperluan pertanian subsisten dan menjamin keberlanjutan lingkungan serta keberlanjutan pangan bagi keluarga. Konsep ekologis tersebut disosialisasikan secara turun temurun oleh perempuan sebagai salah satu penjaga pengetahuan lokal masyarakat Arfak. Namun, dalam kenyataannya terdapat ancaman terutama pemekaran wilayah dan proses transfer pengetahuan terhadap praktik pertanian subsisten yang berkelanjutan berdasarkan konsep ekologi masyarakat Arfak.
\end{abstract}

Kata kunci: Igya ser hanjob, masyarakat adat arfak, pertanian berkelanjutan, pengetahuan lokal

\section{ABSTRACT}

Land as a production factor requires good management, especially in the Arfak Mountains with extreme topography. The high biodiversity here makes this region a conservation area, and its climate makes the Arfak Mountains a center of highland vegetable production in the Province of West Papua. This research in Indud, Ubesia, and Taigei villages describes how Arfak farmers apply their local knowledge, namely the concept of igya ser hanjob in managing land to support sustainable highland vegetable farming. This study used a qualitative approach with inductive methods and case study techniques to document the knowledge and experience of 30 Arfak farmers in a highland vegetable farming system selected by snowball techniques. Data was collected through interviews (individuals and groups) and observations. This study found that sustainable soil management in highland vegetable farming activities is based on the ecological concept of the Arfak community, namely igya ser hanjob. This concept regulates the right managed areas for subsistence agricultural purposes and ensures families' environmental sustainability and food sustainability. The ecological concept is socialized through generations by women as one of the custodians of local knowledge of the Arfak people. However, in reality, there is a threat, especially the expansion of the region and transferring knowledge to sustainable subsistence agricultural practices based on the ecological concept of the Arfak people.

Keywords: Igya ser hanjob, indigenous knowledge, indigenous people of arfak, sustainable agricultural

\section{PENDAHULUAN}

Masyarakat Arfak telah lama hidup dari pertanian subsisten baik dengan sistem pertanian menetap maupun perladangan berpindah (shifting cultivation). Salah satu komoditas yang diusahakan adalah beberapa jenis tanaman sayuran dataran tinggi, yakni

Program Studi Agribisnis, Jurusan Sosial Ekonomi Pertanian, Fakultas Pertanian, Universitas Papua, JIn. Gunung Salju Amban Manokwari-Papua Barat, 98314

* Penulis Korespondensi: Email: els_katmo20@yahoo.com bawang daun (Allium schoenoprasum), seledri (Apium graveolens), wortel (Daucus carota), buncis (Phaseolus vulgaris), sawi (Brassica rapa), dan kol (Brassica oleracea). Pegunungan Arfak (Pegaf) terletak pada ketinggian 2.950 mdpl dengan topografi yang didominasi oleh wilayah perbukitan dan pegunungan (kawasan datar kurang dari $2 \%$ ) dengan kemiringan 1-25\%, menyebabkan pembentukan tanah tidak stabil akibat proses destruksi alam berupa longsor dan erosi (Wambrauw et al. 2015). Selain itu, Wambrauw et al. (2015) menambahkan bahwa tanah di Pegaf mempunyai retensi hara yang rendah 
sehingga diperlukan input seperti pupuk organik. Areal pertanian tidak dapat diperluas karena kondisi geografis selain penetapan Kabupaten Pegaf sebagai kawasan cagar alam (luas 68.325 ha). Surat Keputusan Gubernur Provinsi Papua Barat No. 5.225/123/Tahun 2015 menjadi dasar pembangunan Papua Barat sebagai provinsi konservasi melalui pengembangan pertanian berkelanjutan.

Masyarakat Arfak menganut konsep ekologis dalam pengelolaan sumber daya dalam termasuk kegiatan pertanian subsisten mereka. Terdapat beberapa penelitian terdahulu yang terkait konsep igya ser hanjob sebagai kearifan lokal dalam pengelolaan lingkungan berkelanjutan dengan sistem pertanian perladangan berpindah yang dipraktikkan secara turun termurun oleh masyarakat setempat. Penelitian terdahulu itu dilaksanakan di kawasan konservasi Cagar Alam Pegunungan Arfak yang tersebar pada ketiga ekosistem, yakni ekosistem hutan hujan dataran rendah (low land forest; < $300 \mathrm{~m}$ ), hutan hujan kaki gunung (foothill forest, 300-1000 m), dan hutan hujan lereng pegunungan (lower montane forest, 1000-2800 m) (Anonim dalam Salosa 2014). Penelitian oleh Tapi et al. (2020) dan Atatribaba (2018) menjelaskan bahwa masyarakat di sekitar hutan hujan dataran rendah menjalankan konsep igya ser hanjob dalam kegiatan berkebun. Secara khusus mereka menggambarkan tekanan penduduk, pemekaran wilayah, dan alih fungsi lahan untuk perkebunan kelapa sawit berkontribusi pada tidak diterapkannya konsep tersebut. Bahkan Ataribaba (2018) menemukan bahwa kepatuhan masyarakat Arfak pada konsep ini bersifat semu dan terisolasi. Alih fungsi lahan untuk pemukiman, jalan, dan pembangunan infrastuktur menggeser kebun masyarakat di wilayah pinggiran (Ataribabar 2018). Studi lainnya oleh Purbokurniawan et al. (2019) serta Mulyadi \& lyai (2016) telah menjelaskan zonasi ekosistem dalam konsep igya ser hanjob untuk kegiatan pertanian. Secara umum studi-studi terdahulu ini menggunakan pendekatan yang beragam (kualitatif dan kuantitaf) dan belum secara spesifik menggambarkan rincian zonasi yang tepat sesuai dengan konsep igya ser hanjob untuk usaha tani tanaman sayuran dataran tinggi. Hal ini penting karena wilayah Pegaf berstatus wilayah konservasi dan merupakan sentra produksi tanaman sayuran dataran tinggi. Tuntutan keberlanjutan ekonomi bagi masyarakat Arfak di Pegaf harus didukung oleh sistem pertanian yang berkelanjutan.

Aspek penting dalam zonasi pada konsep igya ser hanjob adalah klasifikassi zona ekologis berbasis pengetahuan lokal masyarakat Arfak yang merujuk pada kondisi tanah dan topografi disertai peruntukannya dalam kegiatan pertanian. Konsep lainnya yang juga merupakan bagian dari sistem pengelolaan lahan adalah perlakuan atas tanah pada pertanian tropika. Sistem pertanian tropika bermasukan luaran yang tinggi (high-external-input agriculture, HEIA) dan penggunaan sumber daya lokal yang intensif dengan masukan luar yang rendah atau tidak sama sekali (low- external-input agriculture, LEIA) dalam kenyataaannya menyebabkan turunnya kualitas lingkungan yang berbahaya bagi organisme termasuk manusia (Mugnisjah 2010). Terobosan baru untuk menemukan sistem pertanian alternatif yang "meniru" ekosistem alami yang "matang" ialah fungsi ekologis dan sistem ekosistem yang oleh Reintjes et al. (dalam Mugnisjah 2010) disebut sebagai sistem pertanian bermasukan rendah (LEISA) atau pertanian berkelanjutan (Benbrook dalam Mugnisjah 2010) atau sistem pertanian berkelanjutan (Edwards dalam Mugnisjah 2010). Pertanian berkelanjutan (Reitjes et al. dalam Mugnisjah 2010) merujuk pada lima prinsip ekologis berikut. 1) Mengamankan kondisi tanah melalui pegolahan bahan organik dan peningkatan kehidupan tanah; 2) Mengoptimumkan ketersediaan hara dan penyeimbang arus hara; 3) Mengurangi kehilangan hara karena radiasi matahari, udara, dan air; 4) Menekan kehilangan oleh hama dan penyakit tanaman dan hewan; dan 5) Mengembangkan penggunaan sumber daya genetik secara komplementer dan sinergis dengan cara pengkombinasian tanaman dan hewan dalam sistem yang terpadu dengan tingkat fungsional yang tinggi.

lgya ser hanjob sebagai konsep pengelolaan lahan berdasarkan pengetahuan lokal masyarakat adat Arfak menjamin keberlanjutan pertanian. Pengetahuan lokal (William \& Muchena 1991) didefinisikan sebagai "native" tetapi bersifat dinamis dan unik, berubah melalui kreativitas dan inovasi serta kontak dengan sistem pengetahuan lainnya (Devaland \& Kamala 2017). Sejauh ini belum banyak pendokumentasian pengetahuan lokal yang mendukung pertanian berkelanjutan pada masyarakat adat. Pengetahuan lokal diturunkan dari generasi ke generasi secara lisan (oral) dan sering kali diintervensi (Berkes et al. dalam Devaland \& Kamaki 2017). Artinya pengetahuan lokal akan hilang seiring bertambahnya usia atau meninggalnya penjaga pengetahuan lokal. Praktik-praktik pertanian lokal menawarkan banyak pendekatan untuk mengembangkan pertanian berkelanjutan (Devaland \& Kamala 2017). Oleh sebab itu, penelitian ini dimaksudkan untuk mendokumentasikan pengetahuan lokal berikut prinsip-prinsip ekologis yang diyakini dan dijalankan oleh masyarakat adat Arfak dalam kegiatan usaha tani sayuran dataran tinggi. Penelitian ini menjadi penting dalam pertanian berkelanjutan, yakni mendokumentasikan zonasi untuk kegiatan pertanian yang berkelanjutan. Pertanian berkelanjutan merupakan pilihan tetap dalam pengembangan Kabupaten Pegaf sebagai wilayah sentra produksi sayuran dataran tinggi di Papua Barat.

\section{METODE PENELITIAN}

Penelitian ini menggunakan pendekatan kualitatif dengan metode induktif sehingga temuannya merupakan dokumentasi hasil pengumpulan data yang bersifat bottom-up. Teknik yang digunakan adalah 
studi kasus karena menggali pengalaman petani Arfak terkait pengetahuan lokal dan cara berpengetahun mereka yang diamati selama satu bulan pada September 2019 di Distrik Taige, Kabupaten Pegaf pada tiga kampong, yaitu Taige, Ubeisa, dan Indud. Subjek utama adalah petani Arfak yang dipilih secara purposif dengan teknik bola salju, berjumlah 15 orang (7 laki-laki dan 8 perempuan) dari kelompok umur 30-60 tahun. Responden ditentukan dimulai dari kelompok tetua adat (elders) baik laki-laki maupun perempuan kemudian dilanjutkan kepada petani perempuan dan seterusnya kepada petani laki-laki. Data dikumpulkan dengan teknik wawancara mendalam (in-depth interview), observasi partisipasin dan diskusi kelompok terfokus (focus group discussion, FGD). Wawancara secara terbuka dan semiterstruktur didasarkan pada panduan pertanyaan yang telah disusun terlebih dahulu. Hasil wawancara direkam dalam catatan lapangan (field note). Hasil pengamatan partisipatif direkam dalam bentuk narasi. Diskusi kelompok terfokus terutama dengan kelompok orang tua baik laki-laki maupun perempuan. FGD menggunakan daftar topik yang telah disiapkan terlebih dahulu.

Data dianalisis secara induktif yang dimulai dengan lima langkah koding (Santana 2010). 1) Dimulai dengan menyusun transkrip verbatim; data yang direkam kemudian buat dalam transkript verbatim; 2) Dilanjutkan dengan memberi tema dan kategori pada transkripsi tersebut; 3) Analisis terfokus untuk memperbandingkan; 4) Analisis mendalam; dan 5) menuliskan tema, mendalami tema, dan menginterpretasi tema-tema yang ditemukan.

\section{HASIL DAN PEMBAHASAN}

Semua responden berasal dari suku besar Arfak terutama sub-suku Sough. Sebagian besar (40\%) subjek berada pada kisaran usia 35-42 tahun dan 20\% lainnya berada pada usia $43-50$ tahun. Sekitar $26 \%$ subjek adalah kelompok tetua. Berdasarkan jenis kelamin, terdapat $67 \%$ perempuan terlibat dalam penelitian ini dan hanya 33\% laki-laki. Hal ini karena usaha tani sayuran ini lebih didominasi oleh perempuan. Sekitar $87 \%$ subjek tidak pernah mengikuti pendidikan formal dan hanya $13 \%$ yang menamatkan perguruan tinggi. Sebagian besar subjek pernah mengikuti penyuluhan pertanian sayuran dataran tinggi dan perikanan air tawar. Sekitar $60 \%$ subjek telah menikah dan terdapat 33\% cerai hidup. Hanya $7 \%$ yang belum menikah. Sebagian besar responden $(40 \%)$ memiliki jumlah anak antara satu dan dua orang, $33 \%$ responden dengan jumlah anak antara tiga dan empat orang, dan $20 \%$ responden memiliki jumlah anak lebih dari empat orang.

Sebelum mengenal tanaman sayuran dataran tinggi masyarakat Arfak telah berkegiatan pertanian subsisten khususnya tanaman pangan dan hortikultura. Bagi masyarakat ini sayuran dataran tinggi merupakan tanaman introduksi pada tahun 1959, diperkenalkan oleh dua orang misionaris asal Amerika Serikat. Mereka memberi bibit tanaman berupa kol, kentang, wortel, bawang daun, jagung, dan lain-lain kepada masyarakat, mengajarkan cara menanam, dan melakukan pembibitan dari hasil panen. Sampai saat ini sebagian besar masyarakat masih menerapkan cara bercocok tanam yang diajarkan oleh para misionaris tersebut. Selanjutnya kegiatan penyuluhan pertanian terkait budi daya sayuran dataran tinggi dan pembagian bibit dilaksanakan oleh Dinas Pertanian.

Lahan yang digunakan untuk budi daya sayuran dataran tinggi umumnya berada dekat pemukiman dengan sistem pertanian menetap dan cenderung campuran dalam satu hamparan yang dibagi dalam sejumlah bedeng. Jumlah bedengan per komoditas berkisar antara lima dan sepuluh dengan panjang antara $5 \mathrm{~m}$ dan $8 \mathrm{~m}$, dan lebar sekitar 0,5-1 $\mathrm{m}$. Luas lahan yang dikelola relatif sempit, yakni kurang dari 0,2 ha dan umumnya ditentukan oleh jumlah tenaga kerja (Tabel 1).

Bawang daun merupakan komoditas sayuran yang banyak diusahakan oleh semua responden $(100 \%)$, Wortel diusahakan oleh $73 \%$ petani, sawi putih oleh $60 \%$ petani, seterusnya kol (33\%); seledri dan buncis diusahakan oleh hanya $13 \%$ responden. Komoditas lainnya seperti buncis dan seledri umumnya ditanam pada lahan campuran, yakni ditumpangsarikan dengan tanaman pangan seperti jagung dan ubi jalar sebagai tanaman pembatas (Gambar 1). Budi daya sayuran masih menggunakan peralatan dan cara-cara tradisional baik dalam pembukaan lahan maupun tahapan kegiatan pertanian lainnya.

Tenaga kerja merupakan salah satu input produksi di dalam kegiatan usaha tani. Tenaga kerja yang digunakan di dalam kegiatan usaha tani adalah tenaga kerja manusia, laki-laki dan perempuan, yang bersumber dari dalam dan luar keluarga. Tidak terdapat penggunaan mesin atau tenaga hewan. Lakilaki mendominasi kegiatan yang melibatkan fisik seperti penebangan pohon dan pembuatan pagar. Hal ini terkait dengan waktu panen dan kemampuan fisik untuk melakukan pekerjaan tersebut. Rata-rata jumlah tenaga kerja yang terlibat pada setiap tahapan kegiatan usaha tani adalah antara dua dan tiga orang sesuai dengan jenis kegiatan usaha tani per komoditas tanaman. Terdapat pembagian kerja berdasarkan gender pada setiap tahapan kegiatan usaha tani. Pada kegiatan panen wortel, perempuan dan laki-laki melakukannya secara bersama-sama (Gambar 2). Rata-rata jumlah jam kerja yang digunakan untuk kegiatan usaha tani adalah enam jam per hari. Pada kegiatan pemasaran, perempuan menghabiskan waktu selama kurang lebih sembilan jam. Pada hari Sabtu dan Minggu tidak ada aktivitas berkebun.

Curahan kerja di dalam penelitian ini dihitung dengan pendekatan hari orang kerja (HOK) pada setiap tahapan kegiatan, mulai dari pembukaan lahan, pengolahan tanah, penanaman, pemeliharaan, pemanenan, dan pemasaran. Umumnya kegiatan 
Table 1 Luas lahan yang dikelola per komoditas sayuran dataran tinggi

\begin{tabular}{|c|c|c|c|c|c|c|c|c|c|c|c|c|}
\hline \multirow{3}{*}{ Luas lahan (ha) } & \multicolumn{12}{|c|}{ Jenis komoditas } \\
\hline & \multicolumn{2}{|c|}{ Buncis } & \multicolumn{2}{|c|}{ Wortel } & \multicolumn{2}{|c|}{ Kol } & \multicolumn{2}{|c|}{ Sawi putih } & \multicolumn{2}{|c|}{ Seledri } & \multicolumn{2}{|c|}{$\begin{array}{c}\text { Bawang } \\
\text { daun }\end{array}$} \\
\hline & $\mathrm{Jml}$ & $\%$ & $\mathrm{Jml}$ & $\%$ & Jml & $\%$ & Jml & $\%$ & $\mathrm{Jml}$ & $\%$ & $\mathrm{Jml}$ & $\%$ \\
\hline Tidak usahakan & 11 & 73 & 4 & 27 & 10 & 67 & 6 & 40 & 12 & 80 & 0 & 0 \\
\hline$\leq 0,01$ & 2 & 13 & 0 & 0 & 0 & 0 & 0 & 0 & 1 & 7 & 0 & 0 \\
\hline $0,01-0,126$ & 2 & 13 & 11 & 73 & 5 & 33 & 9 & 60 & 2 & 13 & 15 & 100 \\
\hline $0,127-0,242$ & 0 & 0 & 0 & 0 & 0 & 0 & 0 & 0 & 0 & 0 & 0 & 0 \\
\hline $0,243-0,358$ & 0 & 0 & 0 & 0 & 0 & 0 & 0 & 0 & 0 & 0 & 0 & 0 \\
\hline $0,359-0,474$ & 0 & 0 & 0 & 0 & 0 & 0 & 0 & 0 & 0 & 0 & 0 & 0 \\
\hline $0,475-0,591$ & 0 & 0 & 0 & 0 & 0 & 0 & 0 & 0 & 0 & 0 & 0 & 0 \\
\hline$\geq 0,592$ & 0 & 0 & 0 & 0 & 0 & 0 & 0 & 0 & 0 & 0 & 0 & 0 \\
\hline Total & 15 & 100 & 15 & & 15 & 100 & 15 & 100 & 15 & 100 & 15 & 100 \\
\hline
\end{tabular}

Keterangan: Jml = Jumlah.

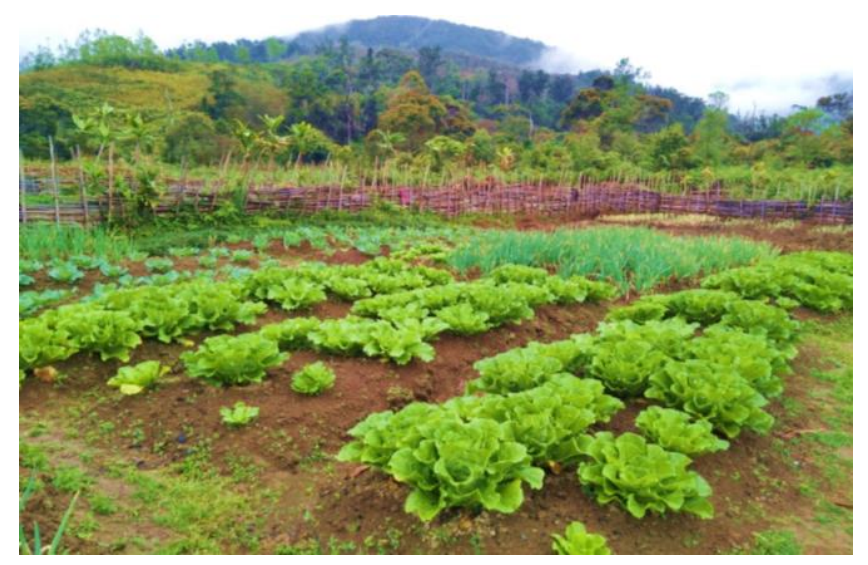

Gambar 1 Kebun sayuran dataran tinggi, sawi dan bawang daun milik Mama Esther, Kampung Ubeisa.

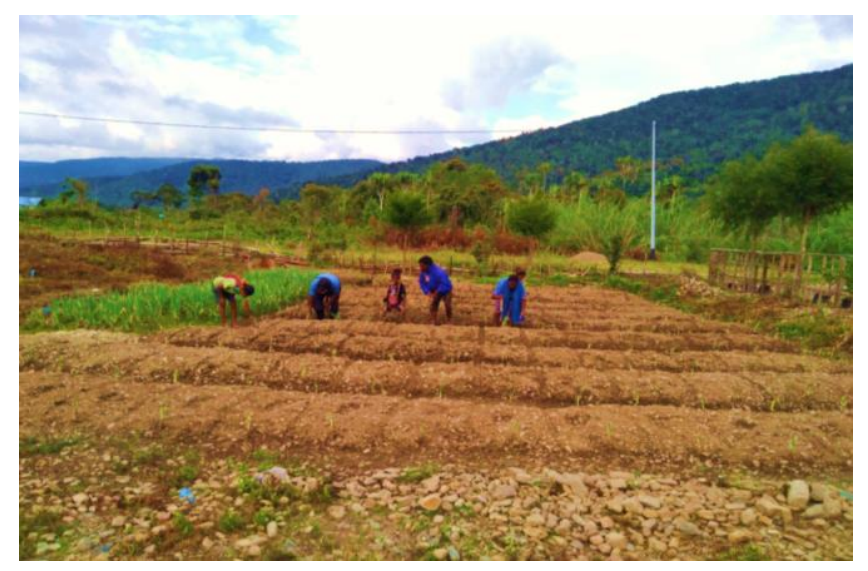

Gambar 2 Kerja bersama dalam penanaman bawang daun, Kampung Ubeisa.

pembukaan lahan dimulai dari pembabatan rumput. Penebangan pohon biasanya lebih rendah karena budi daya sayuran dataran tinggi dipraktikkan dengan sistem menetap. Curahan kerja pada setiap tahapan kegiatan usaha tani berbeda berdasarkan gender pada setiap komoditas. Secara rinci curahan kerja pada kegiatan usaha tani dapat dilihat pada Tabel 2.

Pengetahuan tentang budi daya sayuran dataran tinggi salah satunya ditentukan oleh pengalaman berusaha tani (dinyatakan dalam tahun) yang dibentuk dari pengalaman sehari-hari dan interaksi dengan komoditas sayuran serta orang lain baik sesama petani, penyuluh, maupun konsumen. Perincian pengalaman berusaha tani dapat dilihat pada Tabel 3.

Pengalaman berusaha tani sayuran dataran tinggi dari $87 \%$ petani Arfak adalah selama 16-20 tahun terutama untuk komoditas buncis, wortel, dan bawang daun, sedangkan kol dan sawi putih telah diusahakan oleh sekitar $67 \%$ responden dalam kurun waktu yang sama. Artinya, komoditas sayuran dataran tinggi telah cukup lama diusahakan oleh petani di Distrik Taige. Walaupun penelitian ini tidak secara khusus menghitung derajat komersialisasi dari kegiatan usaha tani sayuran tersebut, hamper semua responden mengemukakan bahwa orientasi usaha tani mereka adalah komersial dan hanya sebagian kecil untuk konsumsi. Umumnya dari sejumlah bedeng sayuran yang diusahakan, mereka akan menyisihkan sekitar satu bedeng dari keseluruhan jenis komoditas untuk dikonsumsi sendiri.

lgya ser hanjob merupakan istilah kearifan lokal Masyarakat Arfak, berupa zonasi wilayah pertanian dan pemanfaatannya untuk melestarikan alam (Purbokurniawan et al. 2019). Prinsip tersebut berasal dari bahasa Hatam, igya berarti kita berdiri di kaki sendiri, ser artinya menjaga, dan hanjop berarti batas. Secara harafiah berarti: kita berdiri untuk menjaga batas. Batas dalam segala segi kehidupan masyarakat adat suku Arfak, baik itu batas kawasan, batas budaya maupun norma-norma sosial yang berlaku (Hastanti \& Yeny dalam Purbokurniawan et al. 2019). Igya ser hanjob terdiri atas empat zona, yaitu bahamti, nimahamti, susti, dan situmti. Zona susti dan situmti merupakan zona pemanfaatan untuk lahan pertanian yang dipakai secara aktif dan intensif. Zona susti merupakan lahan pertanian dengan sistem budi daya tanaman tidak menetap atau berpindah dan pola tanam campuran dengan cara tumpang sari. Zona situmti adalah lahan pertanian dengan sistem budi daya tanaman menetap dan pola tanam campuran dengan cara tanam tidak serempak. Pengetahuan lokal ini juga diterapkan di setiap tahapan kegiatan usaha tani mereka termasuk pengelolaan lahan untuk bercocok tanam yang sudah turun temurun. 
Tabel 2 Rata-rata curahan kerja pada usaha tani sayuran dataran tinggi

\begin{tabular}{|c|c|c|c|c|c|c|c|c|c|c|c|c|}
\hline \multirow{3}{*}{ Tahapan kegiatan } & \multicolumn{12}{|c|}{$\begin{array}{l}\text { Rata-rata curahan kerja pada kegiatan usaha tani } \\
\text { sayuran dataran tinggi (HOK)/tahun }\end{array}$} \\
\hline & \multicolumn{2}{|c|}{ Buncis } & \multicolumn{2}{|c|}{ Wortel } & \multicolumn{2}{|c|}{$\begin{array}{l}\text { Bawang } \\
\text { daun }\end{array}$} & \multicolumn{2}{|c|}{ Sawi putih } & \multicolumn{2}{|c|}{ Kol } & \multicolumn{2}{|c|}{ Seledri } \\
\hline & $P$ & $\mathrm{~L}$ & $\mathrm{P}$ & $\mathrm{L}$ & $\mathrm{P}$ & $\mathrm{L}$ & $\mathrm{P}$ & $\mathrm{L}$ & $\mathrm{P}$ & $\mathrm{L}$ & $\mathrm{P}$ & $\mathrm{L}$ \\
\hline Penebangan pohon & 0 & 0,8 & 0 & 0 & 0 & 0 & 0 & 0 & 0 & 0 & 0 & 0 \\
\hline Pembabatan rumput & 12 & 0 & 12 & 0 & 12 & 0 & 12 & 0 & 12 & 0 & 12 & 0 \\
\hline Pembakaran kebun tahap I & 12 & 0 & 0 & 0 & 0 & 0 & 0 & 0 & 0 & 0 & 0 & 0 \\
\hline Pembakaran kebun tahap II & 12 & 0 & 0 & 0 & 0 & 0 & 0 & 0 & 0 & 0 & 0 & 0 \\
\hline Pembuatan pagar & 0 & 0.8 & 0 & 12 & 0 & 12 & 0 & 12 & 0 & 12 & 0 & 12 \\
\hline Pengolahan tanah & 0 & 0 & 0 & 12 & 0 & 12 & 0 & 12 & 0 & 12 & 0 & 12 \\
\hline Penanaman & 8 & 0 & 12 & 0 & 12 & 0 & 12 & 0 & 0 & 12 & 12 & 0 \\
\hline Pemasangan lanjaran & 8 & 0 & 0 & 0 & 0 & 0 & 0 & 0 & 0 & 0 & 0 & 0 \\
\hline Pengendalian gulma & 8 & 0 & 12 & 0 & 12 & 0 & 12 & 0 & 0 & 12 & 12 & 0 \\
\hline Pemupukan & 8 & 0 & 8 & 0 & 8 & 0 & 8 & 0 & 0 & 8 & 8 & 0 \\
\hline $\begin{array}{l}\text { Pemberantasan hama } \\
\text { penyakit }\end{array}$ & 0 & 0 & 8 & 0 & 8 & 0 & 8 & 0 & 0 & 8 & 8 & 0 \\
\hline Panen & 8 & 0 & 8 & 0 & 8 & 0 & 8 & 0 & 0 & 8 & 8 & 0 \\
\hline Pemasaran & 12 & 0 & 12 & 0 & 12 & 0 & 12 & 0 & 0 & 12 & 12 & 0 \\
\hline
\end{tabular}

Keterangan: $\mathrm{P}=$ Panjang, $\mathrm{L}=$ Lebar, dan $\mathrm{HOK}=$ Hari orang kerja.

Tabel 3 Lama berusaha tani sayuran dataran tinggi

\begin{tabular}{|c|c|c|c|c|c|c|c|c|c|c|c|c|}
\hline \multirow{2}{*}{ Lama usaha (tahun) } & \multicolumn{2}{|c|}{ Buncis } & \multicolumn{2}{|c|}{ Wortel } & \multicolumn{2}{|c|}{$\begin{array}{c}\text { Bawang } \\
\text { daun }\end{array}$} & \multicolumn{2}{|c|}{ Kol } & \multicolumn{2}{|c|}{ Sawi putih } & \multicolumn{2}{|c|}{ Seledri } \\
\hline & Jml & $\%$ & Jml & $\%$ & $\mathrm{Jml}$ & $\%$ & $\mathrm{Jml}$ & $\%$ & Jml & $\%$ & Jml & $\%$ \\
\hline $5-10$ & 2 & 13 & 2 & 13 & 2 & 13 & 2 & 13 & 2 & 13 & 2 & 13 \\
\hline $11-15$ & 0 & 0 & 0 & 0 & 0 & 0 & 3 & 20 & 3 & 20 & 0 & 0 \\
\hline $16-20$ & 13 & 87 & 13 & 87 & 13 & 87 & 10 & 67 & 10 & 67 & 13 & 87 \\
\hline Total & 15 & 100 & 15 & 100 & 15 & 100 & 15 & 100 & 15 & 100 & 15 & 100 \\
\hline
\end{tabular}

Keterangan: $\mathrm{Jml}=$ Jumlah.

Dalam menjalankan kegiatan usaha tani sayuran dataran tinggi petani Arfak telah menerapkan sistem pertanian berkelanjutan berdasarkan pengetahuan lokal mereka. Petani di Distrik Taige menganut konsep igya ser hanjob dengan membagi wilayah kelola menjadi empat zona. Keempat zona tersebut adalah: (1) Zona bahamti berada pada kawasan yang tinggi dari Pegunungan Arfak; (2) Zona nimahamti (nihamti) berada di sekitar Kawasan dengan topografi lerenglereng terjal; (3) Zona susti berada di sekitar lereng yang tidak terlalu terjal; dan (4) Zona situmti, berada pada kaki bukit yang datar sampai ke sekitar pemukiman (Purbokurniawan et al. 2019). Tetapi penelitian ini menemukan bahwa terdapat tiga wilayah kelola dari landscape Pegunungan Arfak yang dimanfaatkan. Hal ini dijelaskan dalam wawancara dengan seorang responden di Kampung Indud, bahwa;

kami hanya mengenal tiga zona dalam prinsip igya ser hanjob, yakni bahamti, susti, dan situmti.

(Zakeus Iriyo, Kampung Indud, 25-09-2019).

Selanjutnya dikemukakan pula bahwa wilayah yang dikelola dan dimanfaatkan oleh masyarakat untuk pertanian adalah wilayah yang berada pada zona susti dan situmti, sedangkan wilayah bahamti adalah gunung yang tidak boleh dikelola bagi kegiatan pertanian. Seorang responden, dalam FGD mengemukakan bahwa:
[Zona] Bahamti punya tanah banyak batu, kami takut akan longsor kalo berkebun di sana, dan gunungnya terlalu tinggi [curam]

(Tinus Towansiba, Kampung Taige, 30-09-2019).

Hal serupa juga disampaikan oleh seorang responden lainnya, bahwa:

Kami sudah tua, tenaga kurang, jadi tidak kuat jalan ke tempat yang jauh, naik gunung. Kami juga takut longsor, selain itu tanahnya [zona bahamti] berbatu. (Lukas Towansiba, Kampung Taige, 30-09-2019).

Kedua responden di atas (Tinus dan Lukas Towansiba) mengemukakan bahamti merupakan kawasan yang rawan longsor dengan topografi yang curam sehingga bukan kawasan yang cocok untuk berkebun. Responden lainnya menjelaskan bahwa lokasi kebun tidak berada di zona bahamti tetapi lokasi ini menjadi tempat menyediakan bahan baku rumah dan kayu bakar.

[Zona] Bahamti kami takut longsor jadi tidak berkebun di situ, bahamti tinggal untuk berburu, mengambil kayu bakar, mangambil kayu buah untuk membangun rumah kaki seribu, mengambil tali rotan untuk pake ikat rumah, pohon besar disensor [chainsaw] atau dibela untuk jadikan papan rumah.

(Orpa Mandacan, Kampung Taige, 30-09-2019) 
Subjek lainnya mengemukakan bahwa bahamti merupakan tempat perburuan dan sumber tanaman obat bagi masyarakat Arfak.

Zona Bahamti Hutan tinggal untuk tahan longsor, hutan tinggal untuk mengambil kayu bakar, hutan tinggal untuk berburu, hutan tinggal untuk mengambl pohon- pohon kecil untuk ikat rumah adat kaki seribu, hutan tinggal untuk mengambil tali rotan untuk ikat rumah adat, hutan tinggal untuk mencari daun atau ramuan obat untuk mencegah penyakit

(Elias Towansiba, Kampung Taige, 30-09-2019)

Seorang responden dan seorang tetua adat, Zakeus Iriyo, dalam wawancara juga menjelaskan hal yang sama dengan yang disampaikan oleh responden lainnya.

untuk berburu, hutan tinggal untuk mencari kayu bakar, hutan tinggal untuk mengambl kayu buah, hutan tinggal untuk mencari tali rotan fungsinya untuk mengikat rumah adat kaki seribu

(Yermia Iryo, Kampung Indud, 25-09-2019)

Hutan bahamti tidak bisa bikin kebun di sana supaya pohon-pohon tinggal [tidak ditebang] untuk menahan tanah supaya tidak longsor. Jadi hutan bahamti untuk tempat ambil kayu bakar dan kayu buah untuk bikin rumah [rumah kaki seribu]. Kami juga hanya ambil pohon-pohon besar untuk papan rumah.

(Zakeus Iriyo, Kampung Indud, 25-09-2019)

Beberapa perempuan terutama yang merupakan kepala keluarga tunggal, menjelaskan bahwa mereka tidak berkebun di zona bahamti dan nihamti karena terlalu jauh dari pemukiman

Kami ini janda jadi berkebun dekat rumah saja, kami buang uang ke gereja [membayar tenaga kerja dari kelompok gereja] untuk bantu buka kebun dekat rumah.

(Deiganus Towansiba, Kampung Ubeisa, 26-092019)

Responden perempuan lainya (Dabida Dowansiba) di dalam sebuah wawancara menjelaskan bahwa:

Kami takut longsor sehingga tidak berkebun, hutan bahamti tinggal untuk anak-anak laki-laki yang sering berburu di atas gunung, mengambil kayu buah untuk ikat rumah adat kaki seribu, untuk mengambil tali rotan funsi untuk mengakat rumah, untuk mengambil daun atau ramuan untuk mengobati penyakit.

(Dabida Dowansiba, Kampung Ubeisa, 29-092019)

Hasil penelitian ini menunjukkan bahwa zona bahamti merupakan zona ekologi yang tidak dikelola karena fungsinya untuk menjaga ekosistem, yakni mencegah longsor. Selain itu, kondisi tanah di zona ini dinilai tidak subur untuk lahan pertanian. Pemanfaatan hutan bahamti adalah sebagai sumber kayu bakar terutama pohon-pohon kering yang telah tumbang dan juga untuk bahan rumah selain berburu, sebagai sumber bahan baku rumah dan tanaman obat-obatan. Tanaman sayuran dataran tinggi umumnya dibudidayakan di zona situmti secara intensif. Kondisi tanah yang baik berdasarkan pengetahuan lokal masyarakat adalah tanah yang berada di zona situmti karena berwarna hitam.

Pengetahuan masyarakat Arfak tentang cara-cara pengolahan tanah telah sesuai dengan pertanian ekologis dalam pertanian berkelanjutan atau LEISA. Pada saat pengolahan lahan, petani sayuran dataran tinggi memberi perlakukan tertentu untuk mengamankan kondisi tanah sebelum penanaman dengan cara mengolah bahan organik dan meningkatkan kehidupan organisme tanah. Contohnya adalah melakukan rotasi dengan cara bera dan memberi input organik berupa serasah daun dan rumput untuk meningkatkan kondisi hayati dan kimia tanah. Pengetahuan lokal juga digunakan untuk penentuan lokasi kebun. Akan tetapi, pada tahapan kegiatan budi daya lainnya selain pengolahan lahan, petani Arfak telah mengombinasikan pengetahuan lokal dan pengetahuan introduksi yang telah membentuk pengetahuan baru yang disebut sebagai pengetahuan hibrid. Akena (2012) mengemukakan bahwa pengetahuan hibrid dibentuk dari interaksi antara penghasil pengetahuan, politisi, afiliasi kelas social, dan simbolisasi identitas kelompok. Kegiatan budi daya didahului dengan menentukan lokasi kebun.

Pemilihan lahan atau lokasi kebun didasarkan pada konsep igya ser hanjob. Di dalam implementasi konsep itu, segi kesuburan tanah dijadikan dasar penentuan wilayah-wilayah yang dikelola untuk kegiatan pertanian. Kesuburan tanah merupakan segi utama dalam penentuan lokasi kebun. Dalam penelitian ini ditemukan bahwa tanah yang subur berada di wilayah situmti yang diindikasikan oleh warna tanah, seperti dikemukakan oleh beberapa responden. Tanah hitam dipahami sebagai tanah yang subur oleh petani lokal. Selain kesuburan tanah, waktu dan tenaga juga menjadi dasar penentuan lokasi kebun.

Tanah yang subur itu tanah warna hitam, itu yang kami pilih untuk kebun.

(Tinus Toansiba, Kampung Taige, 30-09-2019)

Umumnya rumah tangga dengan kepala keluarga perempuan memiliki keterbatasan tenaga kerja selain aktivitas domestik dan sosial lainnya yang juga menggangu waktu kerja di kebun. Artinya, selain keberlanjutan lingkungan, keberlanjutan sosial juga menjadi segi penting dalam penentuan lokasi kebun. Zona situmti sangat tepat bagi petani perempuan karena efisiensi waktu dengan kegiatan reproduktif dan sosial oleh perempuan. Hal ini selaras dengan apa yang dikemukakan oleh Purbokurniawan et al. (2019) bahwa "ibu rumah tangga sangat berperan dalam melakukan aktivitas budi daya".

Pembukaan lahan terdiri ats beberapa kegiatan, yakni pembabatan rumput, penebangan pohon, pembuatan pagar, pembakaran, dan pengolahan 
tanam. Petani Arfak di Distrik Taige yang mengusahakan sayuran dataran tinggi tidak melakukan perladangan berpindah atau pertanian menetap karena umunya lokasi kebun mereka berada di zona situmti. Pada zona situmtim biasanya tanah diolah. Tanah diolah dalam dua tahapan, yakni pembalikan tanah dengan menggunakan cangkul, kemudian tanah dihaluskan pada tahap berikutnya. Setelah itu, dibuat bedeng dengan ukuran panjang sekitar $3 \mathrm{~m}$ dan lebar $1,5 \mathrm{~m}$. Pengetahuan tentang pembuatan bedengan ini diperoleh dari Dinas Pertanian melalui penyuluhan lapangan. Pada masa lalu ketika diperkenalkan pada sayuran dataran tinggi ini oleh misionaris, penanaman didahului dengan pengolahan tanah.

Hasil wawancara dengan seorang responden menjelaskan bahwa pada zona situmti kesuburan tanah juga akan menurun setelah tanah tersebut digarap untuk ditanami sayuran dataran tinggi. Namun, berdasarkan pengetahuan masyarakat, hal itu biasanya terjadi setelah dua kali musim tanam. Setelah dipastikan bahwa tanah tidak lagi subur, petani akan memberi perlakukan untuk meningkatkan kesuburan tanah di zona situmti. Lahan dibera selama kurang lebih dua sampai tiga bulan kemudian dipupuk untuk meningkatkan kesuburan tanah. Pemupukan yang dimaksudkan seperti dijelaskan dalam sebuah wawancara ialah

memberikan daun dan rumput busuk taru[h] di atas permukaan tanah atau gale [gali] tanah masukkan daun atau rumput dalam tanah, dan pupuk kompos dari tanah, kayu, dan lain.

(Lukas Towansiba, Kampung Taige, 22 Oktober 2019)

Pernyataan responden di atas menunjukkan bahwa pengolahan tanah oleh petani sayuran di Kampung Taige dikerjakan berdasarkan pengetahuan yang mereka miliki.

Pemupukan merupakan salah satu bagian dari pengolahan kesuburan lahan dan biasanya dikerjakan sebelum penanaman. Pupuk organik yang diaplikan adalah yang dihasilkan sendiri. Pemupukan ini ditujukan untuk mengoptimumkan ketersediaan unsur hara secara organik. Dalam wawancara, seorang responden mengemukakan bahwa mereka biasanya menggunakan tumbuhan-tumbuhan tertentu yang memiliki fungsi membantu kesuburan tanah.

Kami biasa pake daun sibe, daun arwop, dan rumput amucro untuk bikin subur tanah, macam jadi pupuk begitu

(Tinus Towansiba, Kampung Taige, 30 09-2019)

Pupuk yang dimaksudkan oleh responden ini berasal dari pengetahuan lokal mereka dan bahan bakunya tersedia secara lokal. Penggunaan daun sibe biasanya dikombinasikan dengan kotoran hewan (babi) bersama dengan ranting-ranting dan daun dari pohon arwop serta rumput amucro (bahasa Sough) yang kemudian diaplikasikan ke dalam lahan setelah dipanen. Rumput amucro biasanya tumbuh di lahan, jadi ketika membabat lahan, rumput ini akan dikumpulkan kemudian digunakan. Setelah dibiarkan membusuk beberapa saat, tanah tersebut kemudian dibalik-balik atau dicampurkan dengan menggunakan sekop untuk siap ditanami kembali. Penggunaan pupuk organik ini telah sesuai dengan prinsip-prinsip ekologis seperti dijelaskan oleh Reitjes et al. dalam Mugnisjah 2010).

Pengetahuan lokal terkait erat dengan pertanian berkelanjutan. Igya ser hanjob, konsep ekologis dalam sistem pengetahuan lokal masyarakat Arfak masih diterapkan oleh dalam mengelola lahan untuk pertanian sampai saat ini. Ocholla \& Akullo dalam Matualage (2011) menyatakan bahwa "indigenous knowledge (IK) ialah seperangkat pengetahuan dan teknologi yang tersimpan dalam memori dan dipraktikkan dalam kehidupan masyarakat dan dikembangkan oleh penduduk asli dalam kondisi tertentu". Pengetahuan dan praktik lokal tentang pertanian berkelanjutan disosialisasikan melalui proses belajar di kebun. Penelitian ini menemukan bahwa anak-anak mengetahui cara bercocok tanam sesuai dengan prinsip-prinsip ekologis berdasarkan pengetahuan dan praktik lokal karena kekerapan mereka mengikuti orangtua ke kebun. Atau dapat dikatakan bahwa proses belajar terjadi melalui praktik langsung di kebun, artinya transfer pengetahuan terjadi di kebun. Proses transfer pengetahuan yang demikian disebut sebagai proses pembelajaran sosial (Bandura dalam Matualage 2011). Hal ini selaras dengan temuan penelitian lain bahwa transfer pengetahuan teknik budi daya ubi jalar pada masyarakat Arfak terjadi melalui pembelajaran sosial dari tokoh-tokoh yang dikenal dan dipanuti di dalam masyarakat Arfak. Tokoh utama bagi masyarakat Arfak dalam proses pembelajaran sosial terkait budi daya ubijalar adalah ibu (Matualage 2011). Merujuk pada Bandura, Matulage (2011) menjelaskan bahwa proses pembelajaran sosial terjadi dalam waktu yang tidak singkat, tetapi berlangsung sepanjang kehidupan seseorang. Proses ini terjadi dalam beberapa tahapan, yakni perhatian (atensi), penyimpanan dalam ingatan (retensi), dan peniruan (reproduksi motorik). Pengetahuan ini akan diterapkan jika seseorang termotivasi yang dapat terjadi jika mendapat penguatan dari dalam dirinya dan lingkungannya. Gambar 3 menggambarkan proses belajar sosial di kebun.

Efektivitas pembelajaran sosial tentang budi daya sayuran dataran tinggi baik berdasarkan pengetahuan yang diperoleh dari generasi sebelumnya maupun pengetahuan hibrid dari para penginjil dan penyuluh pertanian tergolong efektif. Hal ini terlihat dari masih diterapkannya pengetahuan lokal tersebut dan usaha tani sayuran dataran tinggi terus dipertahankan.

Oleh sebab itu, pengetahuan lokal tentang pertanian berkelanjutan pada masyarakat berpotensi berlanjut jika aktivitas berkebun masih terus dipraktikkan oleh masyarakat Arfak. Ada dua hal yang diduga memengaruhi pertanian berkelanjutan di Distrik 


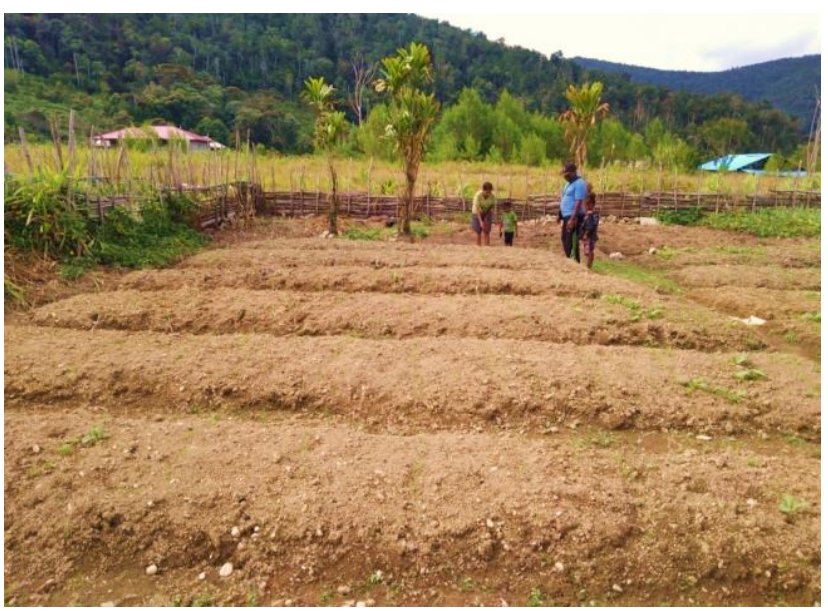

Gambar 3 Proses transfer pengetahuan di kebun dari orangtua kepada anak.

Taige bahkan di Kabupaten Pegaf. Pertama, transfer konsep igya ser hanjob dan praktik pertanian berkelanjutan akan hilang jika aktivitas berkebun tidak lagi dikerjakan. Penelitian Mulyadi \& lyai (2016) menunjukkan bahwa nilai-nilai budaya dan inovasi pertanian berpengaruh nyata pada motivasi masyarakat Arfak berkegiatan pertanian. Pertanian [kebun dan berkebun] menurut Mulyadi \& lyai (2016) secara budaya mempertemukan keluarga, merupakan sarana untuk aktualisasi diri melalui bekerja, dan mempertahankan eksistensi masyarakat Arfak. Artinya kegiatan pertanian tidak akan mati begitu saja walaupun telah banyak masyarakat Arfak yang tidak lagi berkebun kerena melanjutkan pendidikan ke luar daerah. Kedua, perkembangan kota sebagai akibat dari pemekaran menyebabkan bertambahnya pemukinan dan pembangunan insfrastuktur yang tentu saja akan menyebabkan alih fungsi lahan produktif pertanian terutama zona situmti yang selama ini diperuntukan untuk pertanian menetap. Oleh sebab itu, konsep igya ser hanjob seharusnya disinergiskan dengan penataan wilayah Kabupaten Pegaf sehingga keberlanjutan lingkungan dan keberlanjutan pertanian di wilayah Pegunungan Arfak dapat tercapai.

\section{KESIMPULAN}

Penelitian ini menyimpulkan lima hal, yaitu 1) Praktik budi daya tanaman sayuran dataran tinggi pada masyarakat Arfak (Sough) di Distrik Taige, terutama pada ketiga kampung yang menjadi lokus penelitian ini (Kampung Indud, Taige, dan Ubeisa) didasarkan pada pengetahuan lokal dan pengetahuan hybrid; 2) Pengetahuan lokal dan atau pengetahuan hiybrid pada masyarakat Arfak di Distrik Taige selaras dengan prinsip-prinsip pertanian ekologis atau prinsip-prinsip pertanian berkelanjutan; 3) Pembelajaran sosial untuk transfer pengetahuan lokal tentang teknik budi daya tanaman sayuran dataran tinggi dari generasi ke generasi cukup efektif; 4) Perempuan Arfak berperan penting dalam transfer pengetahuan lokal untuk menjamin pertanian yang berkelanjutan; dan 5) Transfer pengetahuan lokal terkait pertanian berkelanjutan melalui proses pembelajaran sosial berjalan baik jika motivasi untuk bertani masih terus ada pada generasi muda saat ini.

Berdasarkan temuan ini dan menyadari pentingnya pengetahuan lokal dan sistem pertanian berkelanjutan, maka pengetahuan lokal perlu didokumentasikan. Transfer pengetahuan lokal saat ini masih dalam bentuk oral dan berpotensi hilang karena tidak tersimpan dalam bentuk lainnya seperti tulisan. Pengakuan atas pengetahuan lokal masyarakat Arfak dalam menjaga keberlanjutan pertanian terutama karena Kabupaten Pegaf merupakan pusat produksi sayuran dataran tinggi di Provinsi Papua Barat dan merupakan kawasan konservasi. Dalam menjaga keberlanjutan pertanian di Pegunungan Arfak, setiap pihak perlu mengacu pada prinsip ekologis igya ser hanjob baik dalam pengembangan pertanian maupun dalam penataan dan pengembangan wilayah di Kabupaten Pegaf.

\section{DAFTAR PUSTAKA}

Akena A. 2012. Critical analysis of the production of western knowledge and its implications for indigenous knowledge and decolonization. Journal of Black Studies. [Internet]. [diunduh 2018 Juni 17]; 34 (6). Tersedia pada: http://jbs.sagepub. com/content/43/6/559

Ataribaba, Yuliana. 2018. Pola Pergeseran Nilai - Nilai Kearifan Lokal Sistem Perladangan Berpindah pada Masyarakat Arfak (Suatu kasus perladangan suku meyakh di kampung Waseki pop Kabupaten Manokwari provinsi Papua Barat. [Tesis]. Universitas Padjajaran. [Internet]. [diunduh 2021 Mei 14]. Tersedia pada https://repository. unpad.ac.id/frontdoor/index

Matualage A. 2016. Keefektifan Pembelajaran Sosial Kearifan Lokal Budi daya Ubi Jalar Di Kalangan Suku Arfak Kabupaten Manokwari. Kawistara. [Internet]. [diunduh 2019 Januari 20]. Tersedia pada https://doi.org/10.22146/kawistara.3907

Mugnisjah, Wahju Q. 2010. Prospek Pertanian Terpadu Sebagai Sistem Pertanian Berkelanjutan di Indonesia: Kasus Rekayasa Spasial di Kabupaten Cianjur. Dalam Chozin, M.A., Sumardjo, Purwanto Roedhy, Prubayanto Ari, Khomsan Ali, Fauzi Ahmad, Suminar B. Kudan, Toharmat Toto dan Hardjanto (Penyunting), Pembangunan Perdesaan dalam Rangka Peningkatan Kesejahteraan Masyarakat. (hal 291-301). Bogor (ID): IPB Press.

Mulyadi, Iyai D. 2016. Pengaruh Nilai Budaya Lokal terhadap Motivasi Bertani Suku Arfak di Papua Barat. Jurnal Peternakan Sriwijaya. 5(1): 18-29. https://doi.org/10.33230/JPS.5.1.2016.3916 
Mulyadi, Sugihen B, Asngari, Pang S, Susanto D. 2009. Kearifan Lokal dan Hambatan Inovasi Pertanian Suku Pedalaman Arfak di Kabupaten Manokwari Papua Barat. Jurnal Penyuluhan. https://doi.org/10.25015/penyuluhan.v5i1.9781

Purbokurniawan, Kubangun S, Noya, Widiastuti NAI. 2019. Zona pemanfaatan lahan pertanian "igya ser hanjob" di sekitar danau anggi Pegunungan Arfak, Papua Barat. Prosiding Seminar Nasional AgroteknologiJurusan Agroteknologi Universitas Islam Negeri Sunan Gunung Djati Bandung. Tersedia pada https://docplayer.info/200934114Zona-pemanfaatan-lahan-pertanian-igya-serhanjob-di-sekitar-danau-anggi-pegunungan-arfakpapua-barat.html

Salosa ST, Suryanto P, Purwanto PH. 2014. Hutan Dalam Kehidupan Masyarakat Hatam Di Lingkungan Cagar Alam Pegunungan Arfak - Jurnal Manusia dan Lingkungan. [Internet]. [diunduh 2021 Mei 14] Tersedia pada: www. journal.ugm.ac.id
Santana K. 2010. Metodologi Penelitian Kualitatif. (Edisi Ke-2). Jakarta (ID): Yayasan Pustaka Obor.

Tapi T, Ganjar K, Iwan S, Agus S. 2020. Shifting Cultivation of Arfak Farmer in Somi and Indisey Villages. Mimbar: Jurnal Sosial Pembangunan. 36(1): $\quad$ 175-185. https://doi.org/10.29313/ mimbar.v36i1.5610

Wambrauw, Ludia T, Tebay S, Irbayanti DN, Maspaitela, Meliala E, Puspitasari A, Widiastuti N, Ahmad M. 2015. Profil Pertanian, Perkebunan, Peternakan, Dan Perikanan Di Kabupaten Pegunungan Arfak. [Laporan Penelitian]. P3FED UNIPA, Manokwari. (16 Febuari 2019).

Williams, David, Muchena O. 1991. Utilizing Indigenous Knowledge system in agricultural education to promote sustainable agriculture. Jurnal of Agricultural Education. [Internet]. [diunduh 2019 Juli 7]. Tersedia pada: File:///H:/ Utilizing Indigenous Knowledge Sistem I. Pdf. https:// doi.org/10.5032/jae.1991.04052 